Grundy, B. D. and Verwijmeren, P. (2016) Disappearing call delay and dividend-protected convertible bonds. Journal of Finance, 71(1), pp. 195-224. (doi:10.1111/jofi.12363)

There may be differences between this version and the published version. You are advised to consult the publisher's version if you wish to cite from it.

This is the peer-reviewed version of the following article: Grundy, B. D. and Verwijmeren, P. (2016) Disappearing call delay and dividendprotected convertible bonds. Journal of Finance, 71(1), pp. 195-224, which has been published in final form at 10.1111/jofi.12363. This article may be used for non-commercial purposes in accordance with Wiley Terms and Conditions for Self-Archiving.

http://eprints.gla.ac.uk/116843/

Deposited on: 17 March 2016

Enlighten - Research publications by members of the University of Glasgow http://eprints.gla.ac.uk 


\title{
Disappearing Call Delay and Dividend-Protected Convertible Bonds
}

\author{
BRUCE D. GRUNDY and PATRICK VERWIJMEREN*
}

\begin{abstract}
Firms do not historically call their convertible bonds as soon as conversion can be forced. A number of explanations for the delay rely on the size of the dividends that bondholders forgo so long as they do not convert. We investigate an important change in convertible security design, namely, dividend protection of convertible bond issues. Dividend protection means that the conversion value of the convertible bond is unaffected by dividend payments and that dividend-related rationales for call delay become moot. We document that call delay is near zero for dividend-protected convertible bonds.
\end{abstract}

\footnotetext{
* We thank Renée Adams, Henk Berkman, Wolfgang Bühler, Marie Dutordoir, Louis Ederington, Pedro Ferreira, Cynthia van Hulle, Abe de Jong, Roman Kräussl, Bryan Lim, Igor Loncarski, Spencer Martin, Ron Masulis, Roni Michaely, Graham Partington, Stefan Petry, Stephen Ross, Chris Veld, Terry Walter, David Yermack, Yuriy Zabolotnyuk, and seminar participants at the 2012 European Finance Association Meetings in Copenhagen, the 2012 La Trobe Finance and Corporate Governance Conference, the 2012 Corporate Finance Day in Ghent, the 2012 Art of Finance FIRN Conference, Erasmus University Rotterdam, La Trobe University, the University of Melbourne, University of Technology Sydney, University of New South Wales, University of Auckland, University of Glasgow, VU University Amsterdam, University of Ljubljana, University of Western Australia, Singapore Management University, and Tilburg University for useful comments.
} 
This paper documents the rapid rise of callable convertibles that are dividend-protected, and the ensuing effect on convertible bond call policy. When a convertible is dividendprotected and a dividend is distributed, the number of shares to be received upon conversion increases so as to leave the bond's conversion value unchanged. We find that call delay is near zero for dividend-protected convertible bonds. The link between dividend protection and diminished call delay highlights the importance of dividends for understanding convertible bond call policy.

Calling a convertible bond will force conversion provided the conversion value exceeds the call price. Ingersoll (1977a) and Brennan and Schwartz (1977) model settings in which shareholder wealth is maximized by calling to force conversion whenever feasible. Forced conversion deprives convertible bondholders of the combined value of the insurance they have as bondholders able to demand the bond's principal value at maturity (rather than the bond's conversion value at maturity) and any income advantage from the coupons they receive in excess of the dividends received in the event of conversion. Ingersoll (1977b) documents that in practice a substantial number of firms delay calling relative to this policy, reporting that on average firms wait until the conversion value exceeds the call price by $43.9 \%$.

Asquith and Mullins (1991) observe that studies on call delay are important since a failure to empirically confirm clear predictions of finance theory calls into question the validity of the models. Not surprisingly, researchers have responded to Ingersoll's analysis by considering alternate theories of convertible bond call policy. Theoretical explanations of call delay can be classified into two groups: explanations that are 
unrelated to the firm's dividend policy, and explanations that are dependent on the firm's dividend policy.

There are two explanations unrelated to dividend policy. One is that the costs of a failed call along with a required call notice period can lead firms to delay calling until a bond's conversion value exceeds its call price by a sufficient safety premium. ${ }^{1}$ The other is that call delay can be a credible signal that management believes that the conversion value of the bond will exceed its face value at maturity and hence that there is little to be gained by forcing conversion early since bondholders will convert at maturity (Harris and Raviv (1985)). ${ }^{2}$

Four additional explanations of call delay are related to the firm's dividend policy. The first two are alternate forms of an argument that a strategy of relying on voluntary conversion can dominate forcing conversion via a call and that a necessary condition for voluntary conversion is that dividends exceed coupons. The first such explanation, due to Ingersoll (1977b), is that if bondholders should be voluntarily converting but are not doing so, then shareholders are better off if management does not call, as calling would wake the "sleeping investors." ${ }^{3}$ The second explanation, proposed by Constantinides and Grundy (1986), is that voluntary conversion induced by high dividends avoids the underwriting costs of a formal call and any costs associated with failed calls. ${ }^{4}$

The third dividend-related rationale for call delay is applicable when forced conversion means the loss of a valuable corporate tax shield. Asquith and Mullins (1991), Campbell, Ederington, and Vankudre (1991), and Asquith (1995) argue that delay can be optimal when the after-tax cost of the coupons that would be paid absent a call is less than the post-conversion dividends to be paid to former bondholders. ${ }^{5}$ This paper 
proposes a fourth dividend-related rationale for call delay in which delay serves as a credible signal that high future dividends are likely to induce voluntary conversion. Less optimistic firms will prefer to call and force conversion rather than to allow their bondholders to continue to receive coupons in excess of the post-conversion dividends that they will receive if forced to convert.

A recent change in the design of convertible bonds whereby convertibles today are dividend-protected is particularly interesting. We establish that all four dividend-related rationales for call delay are inapplicable if the convertible is dividend-protected, whereas the two non dividend-related rationales imply little or no difference in the delays expected for dividend-protected and non dividend-protected convertibles. Thus, we predict that if the dividend-related rationales are important, then call delays for dividendprotected convertible bonds will be less than the delays observed for convertibles without dividend protection.

Ours is the first study of call delays to include dividend-protected convertibles. We examine call decisions prior to January 1, 2012 for 471 callable convertible bonds issued in the period 2000 to 2008. There are no dividend-protected convertible bonds in our sample in 2000, while $61 \%$ of the convertibles issued in 2003 are dividend-protected, and by 2005 this percentage is $100 \%$. The average call delay is substantial (67.22 days) for the non dividend-protected convertible bonds in our sample. For the dividend-protected convertibles, the average call delay is only 2.47 days. As predicted, call delay for dividend-protected convertibles is less than that for non dividend-protected convertibles in fact, it is near zero. 
For the non dividend-protected convertibles in our sample, call delay is significantly longer for high-dividend firms (181 days on average) than it is for low-dividend firms (18 days on average), while for the dividend-protected convertibles, the size of the dividend is not an important determinant of call delay. This result together with the near-zero call delay for dividend-protected convertibles highlight the importance of dividends for understanding past call delays, with dividend-related rationales for call delay being the dominant determinant of call delay for non dividend-protected convertible bonds. The near-zero call delay of dividend-protected convertibles also highlights the importance of the early Ingersoll (1977a) and Brennan and Schwartz (1977) predictions of call policy, and confirms that finance theory can be highly useful in understanding managerial behavior.

The remainder of this paper is organized as follows. Section I shows that it is never optimal to voluntarily convert a dividend-protected convertible bond and establishes that all dividend-related rationales for delay are inapplicable when the convertible is dividendprotected. Section II describes the data set. Section III documents that delays are shorter for dividend-protected convertibles than for non dividend-protected convertibles. Section III also confirms prior evidence on the importance of dividends for understanding call delay by documenting a positive link between delay and dividends for non dividendprotected convertibles in our more recent sample. Section IV establishes robustness of our results by controlling for the role of a safety premium in explaining call delay as well as a secular decline in call delay over time. Section V explores possible causes of the change in security design, namely, a belief that dividends were likely to increase and the 
increasing involvement of hedge funds in the convertible bond market. Section VI concludes.

\section{Dividend Protection and Call Policy}

Although convertible bonds issued in the $20^{\text {th }}$ century were protected against stock dividends, stock splits, and extraordinary cash dividends, the bonds' conversion rates were not adjusted for regular cash dividends. In this section we first describe the protection against regular cash dividends that was introduced in the early 2000s. We then consider the implications of dividend protection for the set of dividend-related and non dividend-related rationales for call delay.

\section{A. The Mechanics of Dividend Protection}

The first convertible bond issue with full dividend protection in our sample is a Vector Group issue in 2001. Most prospectuses of dividend-protected convertibles have a sentence describing a conversion rate adjustment of the form "Subject to the terms of the indenture, we will adjust the conversion rate for cash dividends or other cash distributions to all or substantially all holders of our common stock.” The typical formula for the adjustment is

$$
C R_{1}=C R_{0} \times \frac{S^{\text {cum div }}}{S^{\text {cum div }}-d},
$$

where $C R_{1}$ is the conversion rate in effect after the payment of a dividend $d$ per share, $C R_{0}$ is the conversion rate in effect prior to the dividend payment, and $S^{\text {cum div }}$ is the cumdividend stock price. ${ }^{6}$ Dividend protection means that the conversion value of the bond is unaffected by the payment of a dividend. ${ }^{7}$ 


\section{B. Dividend Protection and Voluntary Conversion}

The adjustment given in Equation (1) guarantees that non liquidating dividends will not induce voluntary conversion. Bondholders who convert early to capture the dividend receive the cum-dividend conversion value of $C R_{0} \times S^{\text {cum div }}$. If the bondholders delay conversion, their bonds will be worth at least their ex-dividend conversion value, $C R_{1} \times\left(S^{\text {cum div }}-d\right)$. Conversion value provides a lower bound since bondholders have the option of demanding the bond's principal value at maturity. Given the conversion rate adjustment, this lower bound on value is

$$
C R_{1} \times\left(S^{\text {cum div }}-d\right)=C R_{0}\left(\frac{S^{\text {cum div }}}{S^{\text {cum div }}-d}\right) \times\left(S^{\text {cum div }}-d\right)=C R_{0} \times S^{\text {cum div }} .
$$

Hence, the bondholder is never better off converting early to capture the dividend.

\section{Dividend Protection and Call Policy}

In this section we begin by describing the four dividend-related explanations for call delay and show that each explanation is inapplicable if the convertible is dividendprotected. We then show that both non dividend-related explanations for call delay (the safety premium and the Harris and Raviv signaling model) are applicable to dividendprotected and non dividend-protected convertibles.

\section{C.1. Dividend Protection, Voluntary Conversion, and Sleeping Investors}

If a call forces conversion, then calling gives the bondholders a claim on the firm worth $\frac{C R}{n+C R} V$, where $C R$ is the conversion rate, $n$ is the pre-conversion number of shares, and $V$ is the value of the firm. Suppose the bond is not dividend-protected and that 
dividends are such that the convertible bondholders should be voluntarily converting, because their claim if they do not convert is worth less than $\frac{C R}{n+C R} V$. Further suppose that some bondholders are not voluntarily converting because they are asleep. It is then optimal to delay calling this non dividend-protected convertible (Ingersoll (1977b)).

Now suppose instead that the convertible is dividend-protected. We have established that it is never in the bondholders' interest to voluntarily convert a dividend-protected bond, which means that their dividend-protected bond is worth at least $\frac{C R}{n+C R} V$. As a result, sleeping through the opportunity to voluntarily convert is optimal for the convertible bondholders, in which case it is in the original shareholders' best interest to call and deprive the bondholder of any extra value the bond might have above its conversion value. Thus, while this dividend-related rationale for call delay might help explain delays in calling non dividend-protected convertibles, it cannot rationalize a delay in calling a dividend-protected convertible.

\section{C.2. Dividend Protection, Voluntary Conversion, and Costs of Failed Calls}

Voluntary conversion avoids the costs of underwriting a call and any costs associated with failed calls. Therefore, if the convertible is not dividend-protected and management is confident that dividends will induce voluntary conversion, then relying on voluntary conversion can be preferred to forcing conversion (Constantinides and Grundy (1986)). But when a convertible is dividend-protected, voluntary conversion is not in the bondholders' interest. Thus, a delay in calling a dividend-protected convertible cannot be rationalized by an expectation of high dividends and future voluntary conversion. 


\section{C.3. Dividend Protection and a Tax-Based Rationale for Call Delay}

Section A of the Appendix formalizes the Asquith and Mullins (1991), Campbell, Ederington, and Vankudre (1991), and Asquith (1995) argument that shareholders may prefer not to force the conversion of a non dividend-protected convertible if conversion means the loss of a valuable tax shield. As shown in the Appendix, if the present value of the dividends to be paid to former convertible bondholders forced to convert were to exceed the after-tax coupon on the convertible, then a firm may find it optimal not to force the conversion of non dividend-protected convertibles.

However, if the convertible is dividend-protected, Section B of the Appendix shows formally that the shareholders are better off by calling and forcing conversion. The reasoning is as follows. When the convertible is dividend-protected and conversion is not forced, convertible bondholders receive coupon income and enjoy an enhancement of their conversion terms in the event of a dividend. In effect, this enhancement compensates them for the dividends they would have received if they had converted. If forced to convert, the bondholders will receive dividends. From the point of view of the firm's shareholders, what differs between these two scenarios is the after-tax cost of the coupon that must be paid so long as the bond is not called. ${ }^{8}$ Since calling avoids this cost, forcing the conversion of an in-the-money dividend-protected convertible dominates delay.

\section{C.4. Dividend Protection and a Dividend-Related Signaling Rationale for Call Delay}

In a dividend-related signaling equilibrium, low-quality firms do not anticipate a future dividend increase and call their non dividend-protected convertibles while highquality firms delay calling and instead rely on high future dividends to induce voluntary 
conversion. It would be costly for the shareholders of a low-quality firm to delay calling in an effort to increase its current share price since a low-quality firm would continue to pay its convertible bondholders coupons in excess of the post-conversion dividends they would receive if forced to convert.

Since a dividend-protected convertible will never be voluntarily converted, a highquality firm with a dividend-protected convertible outstanding could not rely on its high dividends to induce voluntary conversion. Irrespective of its quality, a firm would owe coupons on its dividend-protected convertibles so long as it did not force conversion, and call delay would not be more costly for low-quality firms than for high-quality firms. As such, no dividend-related signaling equilibrium exists if the convertible is dividendprotected, and shareholders are always better off by calling and forcing conversion. ${ }^{9}$

\section{C.5. Dividend Protection and the Safety Premium Rationale for Call Delay}

Firms might delay calling until a bond's conversion value exceeds its call price by a sufficient amount, so that the likelihood of a subsequent share price decline that would lead the bondholders not to convert at the end of the notice period is considered low enough. Asquith and Mullins (1991) investigate a 20\% safety premium and state that in practice managers use a $20 \%$ to $25 \%$ rule. This rationale applies equally to dividendprotected and non dividend-protected convertibles.

\section{C.6. Dividend Protection and the Harris-Raviv Signaling Rationale for Call Delay}

Harris and Raviv (1985) develop a signaling model (the HR model) in which highquality firms delay calling non dividend-protected convertible bonds and low-quality firms call non dividend-protected convertible bonds. The model assumes that conversion at maturity is more likely to occur for high-quality firms and hence that the value of the 
insurance that convertible bondholders retain so long as the bond is not called is larger for low-quality firms. If a low-quality firm were to delay calling in order to mimic a highquality firm, it would allow its bondholders to retain this valuable insurance. The Harris and Raviv (1985) model assumes for simplicity that the underlying firm does not pay dividends prior to the convertible's maturity.

For dividend protection to be relevant in a HR-type signaling model, it must be the case that the underlying firm pays dividends, and the HR model can be generalized to allow for dividends. However, a necessary condition for the existence of a HR signaling equilibrium is that the bondholders do not voluntarily convert in order to capture the dividend, as the insurance feature could then never pay off. This condition requires that dividends be sufficiently small if the HR model is to explain a delay in calling a non dividend-protected convertible. ${ }^{10}$

When the dividend is sufficiently small, there will only be a minor change to the conversion rate of a dividend-protected convertible after a dividend payment. It can be shown that if the initial conversion rate of a dividend-protected convertible is set such that the dividend-protected convertible has the same value at the time of issue as a non dividend-protected convertible, and if a HR signaling equilibrium exists for a non dividend-protected convertible, then a HR signaling equilibrium will also likely exist for a dividend-protected convertible. As a result, to the extent that call delays for non dividend-protected convertibles reflect a HR signaling equilibrium, then dividendprotected convertibles issued by otherwise equivalent firms will exhibit a similar call delay. ${ }^{11}$

\section{C.7. The Relation Between Dividend Protection and Call Delay}


Sections I.C.1 to I.C.4 above show that the four dividend-related rationales for call delay are only applicable when the convertible is non dividend-protected and hence, while a delay in calling a non dividend-protected convertible might be explained by future dividends, a delay in calling a dividend-protected convertible cannot be so rationalized. Sections I.C.5 and I.C.6 show that when either of the two non dividendrelated rationales explain the delay in calling a non dividend-protected convertible, we would expect to see a similar delay in calling an otherwise equivalent dividend-protected convertible.

We conclude that call delays for dividend-protected convertibles will be either shorter or comparable to delays for non dividend-protected convertibles. If call delays are shorter for dividend-protected convertibles than for non dividend-protected convertibles, then call delays must be explained at least in part by one or more of the dividend-related explanations. Further, if call delays for non dividend-protected convertibles are entirely explained by one or more of the dividend-related explanations, then dividend-protected convertibles will be called without delay and call delays will only be observed for non dividend-protected convertibles.

\section{Data}

We identify the set of convertible bonds issued by U.S. industrial companies over the period January 2000 to December 2008 by examining the Securities Data Company $(S D C)$ database of new corporate issues. We require that the issuing firms have an offering prospectus available on the SEC's Edgar database and that the convertibles have call features. ${ }^{12}$ We exclude convertible preferred stock, exchangeable securities, convertibles issued in units with equity, and floating rate convertibles. This leaves 471 
convertible bond issues that have call features and for which we have detailed information on their design characteristics. Most dividend-protected convertibles have protection in the form of the adjustment to the conversion terms given by Equation (1) for all cash dividends, regardless of the size of the dividend. However, a subset of issues only provides protection when the cash dividend exceeds a specified dollar amount or a specified dividend yield. The specified levels are typically relatively low and are called a “dividend threshold.” For example, the prospectus for a 2004 Reebok International issue states that

"the conversion rate will be adjusted if we make regular cash dividends to all or substantially all holders of our common stock in excess of \$0.15 per share in any semi-annual period.”

Reebok paid a semi-annual dividend of exactly \$0.15 per share in 2004 and 2005 (representing an annual dividend yield of about $0.7 \%$ ) and the conversion rate was not adjusted in these years.

In our empirical analysis we only classify a convertible with a dividend threshold as dividend-protected when the threshold multiplied by the conversion rate is smaller than the after-tax coupon. When the dividend threshold multiplied by the conversion rate is larger than the after-tax coupon, a firm could potentially justify not calling on the basis of the tax wedge argument if it were to pay the threshold dividend.

Our sample of 471 convertible bonds contains 43 convertible bonds with a minimum threshold amount expressed in dollar terms and 26 convertible bonds with a minimum threshold dividend yield. For 40 of the 43 convertible bonds with a minimum dollar threshold amount, the conversion rate multiplied by the threshold dividend amount per 
share is less than the after-tax coupon and we classify these bonds as protected. ${ }^{13}$ For the other three bonds the partial protection could potentially be used to justify not calling and hence we classify these bonds as unprotected.

The 26 bonds in our sample with relatively low threshold dividend yields have threshold yields of $1 \%, 1.25 \%, 1.4 \%, 2 \%, 2.5 \%$, and $3.75 \%$. For 12 of the 26 convertible bonds the conversion rate times the threshold dividend yield times the stock price at the time of the convertible's issuance is less than the after-tax coupon. We classify these convertible bonds as dividend-protected and classify the remaining 14 bonds with threshold yields as unprotected. ${ }^{14}$

Panel A of Table I provides descriptive statistics for the 471 convertible bonds. We observe that $60 \%$ of the convertible bonds are protected against regular cash dividends. Panel B shows the percentage of convertible bonds with dividend protection by year of issue. Consistent with observations in Choi, Getmansky, and Tookes (2009) and Lewis and Verwijmeren (2011), a relatively high number of convertibles are issued in 2001, 2003, and 2004. Before 2003, the vast majority of convertible bonds are not dividendprotected, while after 2003 the large majority of convertibles bonds are dividendprotected. Table II shows whether and how the convertible bonds in our sample are retired. We search for information on call announcements in Factiva, the FISD Mergent database, and firms’ annual reports. We also search Factiva, annual reports, and delisting classifications in CRSP for whether a convertible is retired in some way other than through a call, namely, as a result of a merger, a bankruptcy, an exchange of the convertible for other securities, a full repurchase of the convertible, a full exercise of a 
put feature by the convertible bondholders, or the full voluntary conversion of the bond. We search all databases until 1-1-2012.

We find that 159 of the 471 bonds were called, 105 were retired as part of a merger, 32 were retired as a result of the issuer's bankruptcy, 13 were exchanged in capital restructurings, and 13 were repurchased. Eight bonds were completely put back to the firm, four bonds were completely voluntarily converted, and 45 bonds matured.

In quantifying call delay, we focus on the length of call delay rather than the size of the call premium, because during the initial years of their lives 432 of the 471 convertibles in our sample cannot be called (enjoy hard call protection) and 112 of the convertibles can only be called if the stock price exceeds the conversion price by a set percentage for a specified number of trading days within a given time period (soft call protection). The effect of both hard and soft call protection is that the call premium can be large when it first becomes possible to force conversion. We measure call delay as the number of trading days relative to this date.

\section{Observed Call Delays for Convertibles with and without Dividend Protection}

We first consider the set of convertible bonds that were called and ask whether there is any difference in call delay for dividend-protected versus non dividend-protected bonds. We then examine the set of bonds that at some stage prior to 1-1-2012 were not protected against a call and were not called when conversion could be forced. Our prediction is that delay should be less common and less lengthy for dividend-protected bonds. A further prediction of the set of dividend-related rationales for delay is that for non dividend-protected convertibles, delay should be higher when the dividends to be received upon conversion are higher. 


\section{A. Call Delay and Called Convertibles}

We classify a convertible as "in-the-money" when the daily closing stock price times the conversion rate exceeds the call price. ${ }^{15}$ We find that 59 of the 159 convertible calls are calls of convertible bonds that are out-of-the-money at the time of the call announcement. Like most prior studies on call policy, we do not focus on these events. In eight cases the call announcement occurs when the convertible is just out of-the-money and the convertible is in-the-money at the end of the notice period. Following Ingersoll (1977b), we classify these eight convertibles as if they were called in-the-money with a call delay of zero. ${ }^{16}$ This leaves 51 convertibles classified as called out-of-the-money and 108 classified as called in-the-money, of which 45 are dividend-protected and 63 are not.

Since dividend-related rationales for call delay do not apply to dividend-protected convertibles, call delays should be shorter for dividend-protected bonds. Panel A of Table III reports the first of the paper's investigations of this basic prediction. Panel A shows the call delay in trading days for convertibles that are called in-the-money, distinguishing between convertibles with and without dividend protection.

We measure the cumulative call delay as the total number of trading days prior to a call announcement on which the convertible is both in-the-money and callable. The average cumulative call delay is 67.22 days for non dividend-protected convertible bonds and only 2.47 days for dividend-protected convertibles. We also report the continuous call delay, defined as the maximum number of trading days before a call announcement on which the convertible is continuously in-the-money and callable. We find that non dividend-protected convertibles are continuously in-the-money for on average of 47.30 days before being called, while dividend-protected convertibles are continuously in-the- 
money for an average of 2.47 days. The difference between the mean call delay for dividend-protected and non dividend-protected convertibles is statistically significant at the $1 \%$ level for both the cumulative and continuous call delay measures.

Interestingly, the median call delay is zero: 39 of the 63 convertible bonds with no dividend protection and 34 of the 45 convertible bonds with dividend protection have zero call delay. Figure 1 shows that the distribution of call delays for non dividendprotected convertibles is right-skewed relative to the distribution for dividend-protected convertibles. We therefore also examine measures other than standard $t$-statistics and report bootstrapped difference-of-means z-statistics. We also calculate, but do not report, the Wilcoxon rank-sum test statistic and the $\chi^{2}$-statistic of the difference in call delay for the two groups. The differences are significant under all of these measures.

\section{B. Call Delay and Convertibles That Have Not Been Called}

Section III.A provides strong evidence that those dividend-protected convertibles that are called in-the-money are called with virtually no delay. This is a necessary, but not sufficient, condition to establish that there is little delay in calling dividend-protected convertibles. To establish the stronger result we must also examine the delay of convertibles that are not called. We therefore examine the set of convertible bonds that at some stage prior to 1-1-2012 were not protected against a call and were not called in-themoney. These bonds either matured, were exchanged or repurchased, were put back to the firm, were retired because the firm merged or went bankrupt, were fully voluntary

converted, were called out-of-the-money, or were still outstanding on 1-1-2012. This set consists of the full sample of 471 convertible bonds minus the 108 convertible bonds that 
were called in-the-money and the 45 bonds that were still call-protected on 1-1-2012. Thus, we examine 318 bonds in this subsection, of which 194 are dividend-protected.

For only 11 of these 318 convertibles was there any missed opportunity to force conversion prior to 1-1-2012. The other 307 convertible bonds were never in-the-money in periods when they were not call-protected. Of the aberrant 11, five fell out-of-themoney after the missed opportunity and were still outstanding on 1-1-2012, three matured, one was voluntary converted, one was called later after it had fallen out-of-themoney, and one was retired in a merger. Only three of these 11 convertibles were dividend-protected. Thus, only three of the 194 dividend-protected bonds that have not been called to date were ever in-the-money and not call-protected at the time.

Panel B of Table III reports the average number of trading days that the conversion option is in-the-money for the 11 non called convertibles with call delay. The average cumulative (continuous) call delay for the three dividend-protected bonds in the set is 13.00 (11.33) days. In contrast, the average cumulative (continuous) call delay is 232.13 (209.38) days for the eight non dividend-protected convertibles. The maximum call delay for the three dividend-protected convertibles is 32 days, while it is 747 days for the eight non dividend-protected bonds. ${ }^{17}$

\section{Cost of Delay for Dividend-Protected Versus Non Dividend-Protected Convertibles}

The Appendix shows that for dividend-protected convertibles, the cost to the firm's shareholders of delaying a call is the sum of the fraction of the cost of future aftercorporate-tax coupons that is borne by the shareholders (as seen in footnote 8) plus the value of the insurance the bondholder retains so long as she has not converted. The average coupon rate on the dividend-protected convertible bonds in our sample is $3.28 \%$, 
and the average offering proceeds are $\$ 246$ million. If a call occurred at the time conversion could first be forced, the average (median) fraction of the shares outstanding that would be held by convertible bondholders is $9.67 \%$ (7.78\%). Thus, if a call is delayed, then on average $90.33 \%$ of the cost of future after-corporate-tax coupons is borne by the firm's shareholders. Given a corporate tax rate of 35\%, these averages indicate an after-tax coupon-related cost of not calling a dividend-protected convertible of $0.9033 \times 0.65 \times 0.0328 \times \$ 246$ million per year, which corresponds to approximately $\$ 4.7$ million per year. The total cost including the value of the insurance convertible bondholders retain so long as they are not forced to convert is greater than $\$ 4.7$ million per year.

Suppose dividend-protected convertibles were to exhibit the same call delay as non dividend-protected convertible bonds. For non dividend-protected bonds, the average length of time between the date when conversion could first be forced and the date of the earliest of the bond's call, full voluntary conversion, maturity or retirement in a merger, or the 1-1-2012 end of the sample period is 139.7 days. ${ }^{18}$ Given a 252-day trading year, an after-corporate-tax annual coupon cost of $\$ 4.7$ million implies that the average aftertax coupon that would be unnecessarily paid if calls of dividend-protected convertibles were delayed by 139.7 days would be $(139.7 / 252) \times \$ 4.7$ million $=\$ 2.6$ million .

For non dividend-protected convertibles the cost of delay is the sum of the difference between the present values of after-corporate-tax coupons and the dividends to be paid to former bondholders prior to the convertible's stated maturity in the event of conversion (as seen in Equation (A1) of the Appendix) plus the insurance component. When the difference between the after-tax coupon and the dividends to be paid in the event of 
conversion is negative, there is an income-related benefit from a delay in calling non dividend-protected convertibles. The 32 instances of call delay for non dividendprotected convertibles (i.e., 24 instances from Panel A and eight from Panel B of Table III) are associated with a present value of dividends that exceeds the present value of coupons by an average of $\$ 0.37$ million.

\section{Call Delay and the Size of the Dividend for Non Dividend-Protected Convertibles}

Panel C of Table III reports the delay for two subsets of called non dividendprotected convertible bonds: convertibles with dividends less than after-tax coupons (low-dividend convertibles) and convertibles with dividends in excess of after-tax coupons (high-dividend convertibles). Dividend-related rationales for call delay predict longer delays for the high-dividend sample of non dividend-protected bonds. Following King and Mauer (2014), we estimate the dividend to be received upon conversion on the basis of the largest annual dividend per share paid during the period starting from when the bond first became callable.

On average, non dividend-protected bonds experience a 10 times longer call delay when dividends exceed after-tax coupons: the average cumulative (continuous) delay is 181 days (127 days) for high-dividend convertibles and only 18 days (13 days) for lowdividend convertibles. The difference is statistically significant and shows that the relevance of dividends for call delay of non dividend-protected bonds as observed in data from the 1980s and 1990s (Asquith and Mullins (1991), Campbell, Ederington, and Vankudre (1991), Ederington, Caton, and Campbell (1997)) extends to our post-1999 sample of non dividend-protected convertible bonds. 
While 30 of the 44 non dividend-protected convertibles issued by low-dividend firms are called without delay, the 14 instances of delay present a potential conundrum. In fact, 10 of the 14 low-dividend non dividend-protected instances of delay relate to firms that do not pay any dividends in the year prior to the first opportunity to force conversion. Still, as a manager's decision to delay could reflect her private information concerning future dividend growth, some of the delay may be explained if dividends were expected to later increase.

If dividend-related rationales for delay can help explain the call delays observed for non dividend-protected convertibles, then non dividend-paying firms that delay calling non dividend-protected convertible bonds should be more likely to initiate dividend payments than other firms. Three of the 10 non dividend-payers initiated dividends within a year of the first missed opportunity to call. To determine whether three out of 10 is an unusually high number of dividend initiators, we consider the set of firm characteristics investigated in the Jagannathan, Stephens, and Weisbach (2000), Fama and French (2001), and Grullon and Michaely (2002) investigations of dividend policy. Controlling for whether the firm has convertibles outstanding, we estimate the relation between yearend firm characteristics and dividend initiation during our sample period. For the 10 non dividend-paying firms, the average value of the logit-estimated probability of beginning to pay dividends within one year given publicly available financial information and the fact that the firm has a convertible outstanding is $7.06 \%$. Given a $7.06 \%$ probability of dividend initiation, the likelihood of observing as many as three initiations in a sample of 10 is only $2.8983 \%$. Hence, we can reject the null that call delay is not an indicator of a future dividend increase. 


\section{Tobit Analysis of Call Delay}

We use a Tobit analysis to confirm our primary prediction of a negative relation between dividend protection and call delay controlling for other variables. The analysis is reported in Table IV. The dependent variable is the log of (one plus call delay). The explanatory variables are a dummy equal to one when the convertible is dividendprotected, the ratio of the dividend to be received upon conversion to the after-tax coupon, the safety premium on the first date that conversion could be forced, the firm's stock return volatility, financial slack, and year dummies based on the year of issue and the year in which conversion could first be forced. Year dummies are likely to be important as the overall likelihood of call delay seems to have declined over time. ${ }^{19}$

Columns (1) and (2) report that our cumulative and continuous measures of call delay are significantly negatively related to dividend protection. Columns (3) and (4) report that for non dividend-protected convertible bonds, the relation between the size of the dividend and call delay is statistically significant at the $5 \%$ level, with higher dividend firms exhibiting longer call delays. Both the negative effect of dividend protection and the positive effect of dividends when convertibles are not dividend-protected are in line with the importance of dividend-related rationales for call delay.

The safety premium is negatively related to call delay, and for the sample of non dividend-protected convertibles this relation is significant at the $5 \%$ level. This result suggests that firms act to reduce the chance of a failed call. The reason that the safety premium is statistically important for non dividend-protected bonds but not for dividendprotected convertibles may be that dividends and (after-tax) coupons will be in "balance" for some of the non dividend-protected bonds, thereby leaving more room for the safety 
premium to come into play. For the dividend-protected convertibles in our sample, a desire to avoid the average after-corporate-tax cost of coupon payments of $\$ 4.7$ million a year, as calculated in Section III.C, is likely to drive the issuer to force conversion as soon as possible. ${ }^{20}$

\section{What Caused the Change in Security Design?}

The redesign of convertible bonds in recent years to incorporate dividend protection raises the interesting question of "Why?" Conversations with practitioners, including the CFOs of early adopters of dividend protection features, suggest that the design change was driven by a belief that dividends were likely to increase. One reason for such a belief may have been the 2003 passage of the Jobs and Growth Tax Relief Reconciliation Act (JGTRRA), which reduced the tax penalty on dividends. ${ }^{21}$

All the convertibles issued in 2003 between January and April are non dividendprotected. In May, the JGTRRA was signed into law and dividend-protected bonds began to be issued. We establish that $17 \%$ of all issues in May were protected. The percentage of protected issues increased to $22 \%$ in June, and to $92 \%$ in July—once the boilerplate was caste, the stamp seems to have been rapidly pressed into service. Finance personnel at firms that were early adopters of dividend protection have suggested to the authors that they viewed dividend protection as a simple method of reducing the difficulty of valuing the convertible at the time of a perceived increase in dividends.

An alternate possible reason for the design change is the increased involvement of hedge funds in the market for convertible bonds since 2000 (Brown et. al. (2012)). Hedge funds combine long positions in convertibles with short positions in the issuer's common stock. Changes in dividend policy have a direct effect on the value of non dividend- 
protected convertibles. Since dividend protection immunizes a convertible bond's conversion value against changes in dividend policy, dividends have a muted effect on the value of a dividend-protected convertible, simplifying valuation. Further, when a convertible is dividend-protected, the call policy that maximizes shareholder wealth is to force conversion as soon as possible. Thus, purely redistributive calls become a relatively predictable function of the stock price and hedge funds can more successfully hedge their positions. As such, hedge funds may prefer dividend-protected convertibles.

Table V reports the results of a logit analysis of the extent to which incorporation of dividend protection in the design of a convertible is explained by both hedge fund involvement in the issue and the passage of the JGTRRA (as a proxy for a post-May 2003 perception of higher dividends). We follow Brown et al. (2012) and obtain hedge fund involvement by downloading convertible registration statements for privately placed convertibles from SEC Edgar. Many registration statements contain the names of the original purchasers of the convertible bonds, and we classify these buyers as hedge funds or non hedge funds. We are able to obtain buyer information for 401 of the 471 convertible bonds issued during the years 2000 to 2008 .

We consider two measures of hedge fund involvement: the fraction of the issue purchased by hedge funds, and the fraction of purchasers of the issue that are hedge funds. The Post-May 2003 dummy takes the value of one for convertibles issued in and after May 2003. Tufano (2003) investigates, inter alia, whether large or small firms lead financial innovation, and thus we include the natural logarithm of the issuing firm's total assets as a control variable in the logit analysis. To examine whether firms with high 
dividends are more likely to use dividend protection than firms that do not pay dividends, we also include the dividend yield in our regression model.

After controlling for whether the issue date precedes or follows the tax law change, both measures of hedge fund involvement enter positively, but the relation is not statistically significant. The strongest driver of the redesign of convertibles bonds is the Post-May 2003 dummy, which is significantly positively related to the inclusion of dividend protection in a bond's design.

\section{Conclusions}

Prior studies of non dividend-protected convertibles find that a substantial number of firms do not call their convertible bonds as soon as the bond's conversion value exceeds the call price. The analyses of Constantinides and Grundy (1986), Asquith and Mullins (1991), and Campbell, Ederington, and Vankudre (1991) suggest that call delays can be optimal provided the dividends that bondholders forgo by not converting are sufficiently high relative to the (after-tax) coupon cost of the bond to the issuing firm.

A recent change in convertible security design has had a significant impact on convertible call delay. The majority of convertible bonds issued since 2003 are dividendprotected, meaning that the conversion value of the bond is not reduced when the stock goes ex-dividend because the conversion rate is increased to offset the ex-dividend decline in the share price. This paper shows that the dividend-related rationales for call delay are inapplicable if the convertible is dividend-protected. Hence, if all delay in calling non dividend-protected convertibles were explained by one or more of the dividend-related rationales for delay, then dividend-protected convertibles would be called without delay. On the other hand, if non dividend-related rationales explained all 
delay in calling non dividend-protected convertibles, then call delays for dividendprotected and non dividend-protected convertibles would be similar.

We document that call delay is shorter for dividend-protected convertibles than for non dividend-protected convertibles, thus establishing that call delay is at least partially explained by the set of dividend-related rationales for delay. Call delay is in fact near zero for dividend-protected convertibles, consistent with dividends being the primary driver of the call delay documented in earlier studies of call policy for non dividendprotected convertibles. As almost all recently issued convertible bonds contain dividend protection features, we predict that long call delays will be rare events in future years. 


\section{Appendix. The Tax Deductibility of Coupons and Call Delay}

In this appendix we first establish conditions under which the tax deductibility of coupon payments provides a rationale for delaying the call of a non dividend-protected convertible. We then show that under the same conditions it is not optimal to delay calling a dividend-protected convertible.

ASSUMPTION 1: The tax shield provided by the convertible's coupon payments is lost if the bond is called, that is, it is prohibitively costly to recapitalize a firm after a forced conversion.

Let $V_{\text {call }}$ denote the total value of both the convertible bondholders' and the original shareholders' claims on the firm if a call is announced. Let $V_{\text {no call }}$ denote the total value if the convertible is not called. Let $c$ denote the total coupon payable on the convertible and let $\tau$ denote the corporate tax rate. $V_{\text {call }}$ and $V_{\text {no call }}$ are related as follows:

$$
V_{\text {call }}=V_{\text {no call }}-\tau P V(c),
$$

which is analogous to the relation between otherwise equivalent levered and unlevered firms.

ASSUMPTION 2: Without loss of generality, the firm will make a single distribution of dividends and coupons on a common date prior to the convertible's maturity.

ASSUMPTION 3: The firm's investment policy is independent of its call policy and hence $d_{\text {call }}=d_{\text {no call }}+c(1-\tau)$.

The variable $d_{\text {call }}$ denotes the total dividend paid over the remaining life of the bond if the convertible is converted prior to the coupon payment (in which case the tax shield 
is lost given Assumption 1). Let $d_{\text {no call }}$ denote the total dividend paid if the convertible is not called. If forced conversion means the loss of a valuable tax shield, then the only way that the firm's investment policy can be unaffected by a call is if the total of the firm's distributions as dividends and coupons is reduced in the event of a call by an amount equal to the lost tax-saving, that is, if $d_{\text {call }}=d_{\text {no call }}+c(1-\tau)$.

ASSUMPTION 4: $\frac{C R}{n+C R} \times d_{\text {call }}<c$.

Satisfaction of this inequality is sufficient to guarantee that a non dividend-protected bond will not be voluntarily converted. Conversion would lead the former bondholders to suffer both a reduction in their income stream and the loss of the insurance provided by the bond.

ASSUMPTION 5: The firm's value is such that a call would force conversion. ASSUMPTION 6: If the convertible is not called, it is certain to be converted at maturity.

The following section establishes the relation between dividends and coupons that must be satisfied if the call of a non dividend-protected convertible is to be optimally delayed when Assumptions 1 to 6 are satisfied. Section B then shows that it is never optimal to delay calling a dividend-protected convertible even if Assumptions 1 to 6 are satisfied.

\section{A. Non Dividend-Protected Convertibles, the Tax Deductibility of Coupons, and Delay}

If the firm calls and forces conversion, the original shareholders' claim on the firm is worth $\frac{n}{n+C R} V_{\text {call }}$. If instead the firm does not call, their claim is worth 


$$
\begin{aligned}
& P V\left(d_{\text {no call }}\right)+\frac{n}{n+C R} P V(\text { ex-distribution firm value }) \\
= & P V\left(d_{\text {no call }}\right)+\frac{n}{n+C R}\left(V_{\text {no call }}-P V(c)-P V\left(d_{\text {no call }}\right)\right) \\
= & P V\left(d_{\text {no call }}\right)+\frac{n}{n+C R}\left(\left(V_{\text {call }}+\tau P V(c)\right)-P V(c)-P V\left(d_{\text {no call }}\right)\right) \\
= & \frac{n}{n+C R} V_{\text {call }}+\frac{C R}{n+C R} P V\left(d_{\text {no call }}\right)-\frac{n}{n+C R}(1-\tau) P V(c) \\
= & \frac{n}{n+C R} V_{\text {call }}+\frac{C R}{n+C R}\left(P V\left(d_{\text {call }}\right)-(1-\tau) P V(c)\right)-\frac{n}{n+C R}(1-\tau) P V(c) \\
= & \frac{n}{n+C R} V_{\text {call }}+\frac{C R}{n+C R} P V\left(d_{\text {call }}\right)-(1-\tau) P V(c) .
\end{aligned}
$$

Thus, when Assumptions 1 to 6 are satisfied, the original shareholders will prefer to delay calling whenever

$$
\frac{C R}{n+C R} P V\left(d_{\text {call }}\right)>(1-\tau) P V(c)
$$

The left-hand side of inequality (A1) is the present value of the dividend income stream paid to former convertible bondholders over the period between the forced conversion and the bond's stated maturity. The right-hand side is the after-tax cost of the coupon stream paid to convertible bondholders in the absence of a call.

When Assumption 6 is not satisfied (i.e., when it is not certain that the bond will be converted at its maturity), condition (A1) becomes a necessary, but not sufficient, condition for delay to be optimal. This is because when Assumption 6 is not satisfied, calling has the additional advantage of depriving the convertible bondholders of the valuable insurance provided by their right not to convert at maturity.

The empirical analysis of Asquith and Mullins (1991), Campbell, Ederington, and Vankudre (1991), and Asquith (1995) can be thought of as an operationalization of the inequality in (A1). These analyses examine pro-forma dividends defined as the product of the observed per-share dividend prior to a call and the conversion ratio as a proxy for the 
quantity on the left-hand side of inequality (A1). These analyses examine non dividendprotected convertibles only and compare the call behavior of firms with pro-forma dividends less than the convertible's after-tax coupons to the call behavior of firms with pro-forma dividends greater than after-tax coupons. Their finding is that call delays are longer for firms with pro-forma dividends greater than after-tax coupons, indicating that high dividends are associated with longer delays.

\section{B. Dividend-Protected Convertibles, the Tax Deductibility of Coupons, and Delay}

Again assume that Assumptions 1 to 6 are satisfied but now consider a dividendprotected convertible. If the firm calls and forces conversion, then the original shareholders' claim on the firm is worth

$$
\frac{n}{n+C R_{0}} V_{\text {call }} \text {. }
$$

If the firm does not call, the conversion ratio will change when the dividend is distributed. The new conversion ratio, $C R_{1}$, is determined by

$$
C R_{1}=C R_{0} \times \frac{S^{\text {cum div }}}{S^{\text {cum div }}-\left(d_{\text {no call }} / n\right)} .
$$

Given Assumption 6,

$$
S^{\text {cum div }}=\frac{\text { ex-distribution firm value }}{n+C R_{1}}+\left(d_{\text {no call }} / n\right) \text {. }
$$

Substituting (A4) into (A3) gives 


$$
\begin{aligned}
C R_{1} & =C R_{0} \times \frac{\frac{\text { ex-distribution firm value }}{n+C R_{1}}+\left(d_{\text {no call }} / n\right)}{\frac{\text { ex-distribution firm value }}{n+C R_{1}}} \\
=C R_{0} \times \frac{n(\text { ex-distribution firm value })+d_{\text {no call }} \times\left(n+C R_{1}\right)}{n(\text { ex-distribution firm value })} & C R_{0} \times n\left(\text { ex-distribution firm value }+d_{\text {no call }}\right) \\
= & n(\text { ex-distribution firm value })-C R_{0} \times d_{\text {no call }}
\end{aligned}
$$

After the bond's conversion at maturity, the fraction of the firm owned by the original shareholders will be

$$
\begin{aligned}
\frac{n}{n+C R_{1}} & =\frac{n}{n+\frac{C R_{0} \times n\left(\text { ex-distribution firm value }+d_{\text {no call }}\right)}{n(\text { ex-distribution firm value })-C R_{0} \times d_{\text {no call }}}} \\
& =\frac{n}{n+C R_{0}}-\frac{C R_{0}}{n+C R_{0}} \times \frac{d_{\text {no call }}}{\text { ex-distribution firm value }}
\end{aligned}
$$

As in Section A of this appendix, if the firm delays calling, the original shareholders' claim on the firm is worth

$$
\begin{aligned}
& P V\left(d_{\text {no call }}\right)+P V\left(\frac{n}{n+C R_{1}} \times \text { ex-distribution firm value }\right) \\
= & P V\left(d_{\text {no call }}\right) \\
& \quad+P V\left(\left(\frac{n}{n+C R_{0}}-\frac{C R_{0}}{n+C R_{0}} \times \frac{d_{\text {no call }}}{\text { ex-distribution firm value }}\right) \times \text { ex-distribution firm value }\right) \\
= & P V\left(d_{\text {no call }}\right)+\frac{n}{n+C R_{0}} P V(\text { ex-distribution firm value })-\frac{C R_{0}}{n+C R_{0}} P V\left(d_{\text {no call }}\right) \\
= & \frac{n}{n+C R_{0}}\left(P V(\text { ex-distribution firm value })+P V\left(d_{\text {no call }}\right)\right) \\
= & \frac{n}{n+C R_{0}}\left(V_{\text {no call }}-P V(c)\right) \\
= & \frac{n}{n+C R_{0}}\left(V_{\text {call }}-(1-\tau) P V(c)\right) .
\end{aligned}
$$


Comparing (A2) and (A5), we see that the original shareholders are always better off forcing the conversion of a dividend-protected convertible. For dividend-protected convertibles a failure to force conversion imposes a cost on the original shareholders equal to a portion of the after-tax cost of coupon payments and delay is never optimal. In contrast, as shown in Section A of this appendix, a non dividend-protected convertible may not be called if dividends are sufficiently high.

Note that the valuation of the original shareholders' claim when the bond is not called as given in (A5) reflects Assumption 6. When Assumption 6 is not satisfied, the convertible bond has additional value due to the insurance provided by the convertible bondholder's right not to convert at maturity. Thus, when Assumption 6 is not satisfied, it must be the case that if the bond is not called, the value of the shareholders' claim on the firm is even less than the value in (A5). Again, the value in (A5) is less than the value of the shareholders' claim if the bond is called and conversion is forced as given in (A2). Thus, we have established in the setting described by Assumptions 1 to 5 that shareholders are always better off by forcing the conversion of in-the-money dividendprotected convertibles, that is, by never delaying the call of a dividend-protected convertible. 


\section{REFERENCES}

Acharya, Sankarshan, 1988, A generalized econometric model and tests of a signaling hypothesis with two discrete signals, Journal of Finance 43, 413-429.

Altintig, Z. Ayca, and Alexander W. Butler, 2005, Are they still called late? The effect of notice period on calls of convertible bonds, Journal of Corporate Finance 11, 337-350.

Asquith, Paul, 1995, Convertible bonds are not called late, Journal of Finance 50, $1275-1289$.

Asquith, Paul, and David W. Mullins, 1991, Convertible debt: Corporate call policy and voluntary conversion, Journal of Finance 46, 1273-1289.

Bali, Rakesh, and Gailen L. Hite, 1998, Ex dividend day stock price behavior: Discreteness or tax-induced clienteles? Journal of Financial Economics 47, 127-159.

Brennan, Michael J., and Eduardo Schwartz, 1977, Convertible bonds: Valuation and optimal strategies for call and conversion, Journal of Finance 32, 1699-1715.

Brown, Stephen J., Bruce D. Grundy, Craig M. Lewis, and Patrick Verwijmeren, 2012, Convertibles and hedge funds as distributors of equity exposure, Review of Financial Studies 25, 3077-3112.

Butler, Alexander W., 2002, Revisiting optimal call policy for convertibles, Financial Analysts Journal 58, 50-55.

Campbell, Cynthia J., Louis H. Ederington, and Prashant Vankudre, 1991, Tax shields, sample-selection bias, and the information content of conversion-forcing bond calls, Journal of Finance 46, 1291-1324. 
Campbell, James A., and William Beranek, 1955, Stock price behavior on ex-dividend dates, Journal of Finance 10, 425-429.

Choi, Darwin, Mila Getmansky, and Heather Tookes, 2009, Convertible bond arbitrage, liquidity externalities and stock prices, Journal of Financial Economics 91, 227-251.

Constantinides, George M., and Bruce D. Grundy, 1986, Call and conversion of convertible corporate bonds: Theory and evidence, Proceedings, Seminar on the Analysis of Security Prices, CRSP, Graduate School of Business, University of Chicago (November 1986), 35-69.

Dunn, Kenneth B., and Kenneth M. Eades, 1989, Voluntary conversion of convertible securities and the optimal call strategy, Journal of Financial Economics 23, 273-301.

Ederington, Louis H., Gary L. Caton, and Cynthia J. Campbell, 1997, To call or not to call convertible debt, Financial Management 26, 22-31.

Ederington, Louis H., and Jeremy C. Goh, 2001, Is a convertible call really bad news? Journal of Business 74, 459-476.

Elton, Edwin J., and Martin J. Gruber, 1970, Marginal stockholder tax rates and the clientele effect, Review of Economics and Statistics 52, 68-74.

Fama, Eugene F., and Kenneth R. French, 2001, Disappearing dividends over time: Changing firm characteristics or lower propensity to pay? Journal of Financial Economics 60, 3-43.

Ferreira, Pedro, and Alain Ousou, 2011, Divining dividends, Wilmott 55, 16-27. 
Geske, Robert, Richard Roll, and Kuldeep Shastri, 1983, Over-the-counter option market dividend protection and "biases" in the Black-Scholes model: A note, Journal of Finance 38, 1271-1277.

Grullon, Gustavo, and Roni Michaely, 2002, Dividends, share repurchases, and the substitution hypothesis, Journal of Finance 57, 1649-1684.

Harris, Milton, and Artur Raviv, 1985, A sequential signaling model of convertible debt call policy, Journal of Finance 40, 1263-1282.

Ingersoll, Jonathan E., 1977a, A contingent-claims valuation of convertible securities, Journal of Financial Economics 4, 289-322.

Ingersoll, Jonathan E., 1977b, An examination of corporate call policy on convertible securities, Journal of Finance 32, 463-478.

Jaffee, Dwight, and Andrei Shleifer, 1990, Costs of financial distress, delayed calls of convertible bonds, and the role of investment banks. Journal of Business 63, S107-S123.

Jagannathan, Murali, Clifford P. Stephens, and Michael S. Weisbach, 2000, Financial flexibility and the choice between dividends and stock repurchases, Journal of Financial Economics 57, 355-384.

Kahan, Marcel, 1995, Anti-dilution provisions in convertible securities, Stanford Journal of Law, Business and Finance 2, 147-165.

King, Tao-Hsien D., and David C. Mauer, 2014, Determinants of corporate call policy for convertible bonds, Journal of Corporate Finance 24, 112-134. 
Lewis, Craig M., and Patrick Verwijmeren, 2011, Convertible security design and contract innovation, Journal of Corporate Finance 17, 809-831.

Merton, Robert C., 1973, Theory of rational option pricing, The Bell Journal of Economics and Management Science 4, 141-183.

Ofer, Aharon, and Ashok Natarajan, 1987, Convertible call policies: An empirical analysis of an information-signaling hypothesis, Journal of Financial Economics 19, 91-108.

Tufano, Peter, 2003, Financial innovation, in George M. Constantinides, Milton Harris, and Rene M. Stulz, eds.: Handbook of the Economics of Finance (Elsevier). 


\section{Cumulative call delay}
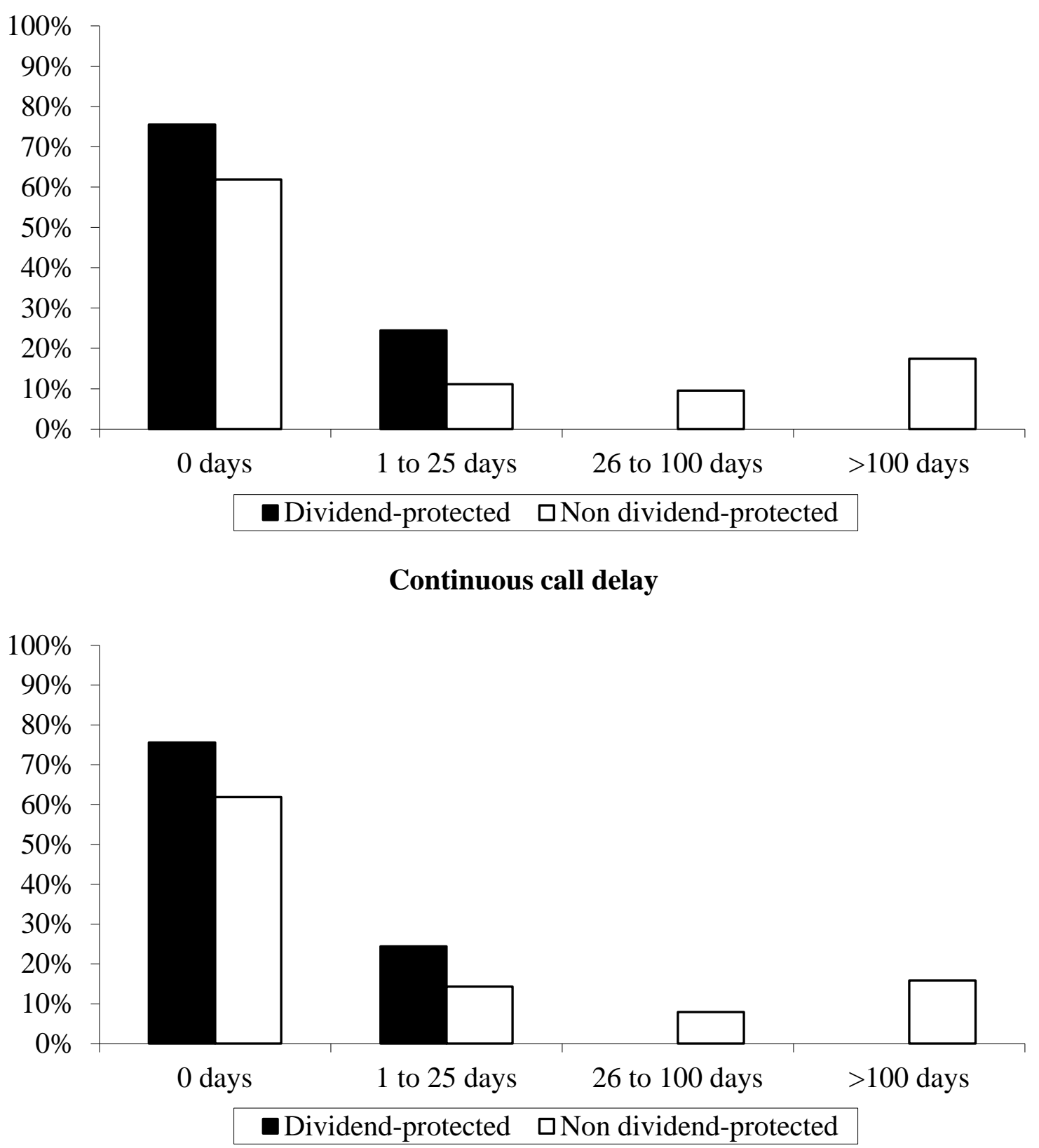

Figure 1. Call delay for convertibles with and without dividend protection. This figure shows the percentage of convertibles with zero call delay, call delay between 1 and 25 days, call delay between 26 and 100 days, and call delay exceeding 100 days. Dividend protection indicates that the conversion rate for the convertible bond will be adjusted for regular cash dividends. Cumulative call delay is the number of trading days before the call announcement date that the convertible bond is in-the-money and callable. Continuous call delay is the number of trading days before the call announcement date that the convertible bond is continuously in-the-money and callable. 


\section{Table I}

Summary Statistics and Issuance of Dividend-Protected Bonds over Time

This table presents descriptive statistics for convertible issues over the period 2000 to 2008. Issue proceeds are gross proceeds in millions of dollars, as reported in SDC. The coupon rate is the yearly coupon as a percentage of the principal. Time to maturity is the number of years between issue and maturity. Years to first call are the number of years that the bond is fully call-protected. Optional redemption is a dummy equal to one if the convertible includes a call feature (that does not put a requirement on the minimum stock price). Provisional redemption is a dummy equal to one if the convertible bond includes a feature specifying that the firm can call the bond provided the stock price exceeds the conversion price by a specified percentage for a specified number of trading days within a given period. Put rights is a dummy equal to one if the convertible bondholder can require the issuer to repurchase the convertible on specified dates at a specified price. Dividend protection is a dummy equal to one if the conversion rate for the convertible bond will be adjusted for regular cash dividends. All information except issue proceeds is obtained from the issue prospectuses. Panel B reports the number of convertible bonds issued each year with and without dividend protection.

\begin{tabular}{|c|c|c|c|c|c|}
\hline \multicolumn{6}{|c|}{ Panel A: Descriptive statistics } \\
\hline & & $\mathrm{N}$ & Mean & Median & St.dev. \\
\hline \multicolumn{2}{|c|}{ Issue proceeds } & 471 & 259 & 150 & 319 \\
\hline \multicolumn{2}{|c|}{ Coupon rate } & 471 & 3.38 & 3.38 & 1.81 \\
\hline \multicolumn{2}{|c|}{ Time to maturity } & 471 & 15.91 & 20.00 & 8.20 \\
\hline \multicolumn{2}{|c|}{ Years to first call } & 471 & 4.42 & 5.00 & 2.02 \\
\hline \multicolumn{2}{|c|}{ Optional redemption } & 471 & 0.92 & 1.00 & 0.28 \\
\hline \multicolumn{2}{|c|}{ Provisional redemption } & 471 & 0.24 & 0.00 & 0.43 \\
\hline \multicolumn{2}{|c|}{ Put rights } & 471 & 0.55 & 1.00 & 0.50 \\
\hline \multicolumn{2}{|c|}{ Dividend protection } & 471 & 0.60 & 1.00 & 0.49 \\
\hline \multicolumn{6}{|c|}{ Panel B: Dividend protection over time } \\
\hline Issue year & $\mathrm{N}$ & $\begin{array}{l}\text { Dividend- } \\
\text { protected }\end{array}$ & & $\begin{array}{l}\text { vidend- } \\
\text { ected }\end{array}$ & $\begin{array}{c}\text { \% dividend- } \\
\text { protected }\end{array}$ \\
\hline 2000 & 39 & 0 & & 9 & $0.0 \%$ \\
\hline 2001 & 69 & 8 & & 1 & $11.6 \%$ \\
\hline 2002 & 36 & 0 & & 6 & $0.0 \%$ \\
\hline 2003 & 122 & 75 & & 7 & $61.5 \%$ \\
\hline 2004 & 106 & 102 & & 4 & $96.2 \%$ \\
\hline 2005 & 38 & 38 & & 0 & $100.0 \%$ \\
\hline 2006 & 26 & 25 & & 1 & $96.2 \%$ \\
\hline 2007 & 20 & 20 & & 0 & $100.0 \%$ \\
\hline 2008 & 15 & 15 & & 0 & $100.0 \%$ \\
\hline Total & 471 & 283 & & 88 & $60.1 \%$ \\
\hline
\end{tabular}




\section{Table II}

\section{Convertible Retirements}

This table shows how the convertible bonds in our sample are retired. The sample consists of convertible bonds issued over the period 2000 to 2008, and we report their status as of January 1, 2012. The classifications are based on information from Factiva, FISD Mergent, CRSP, and firms' annual reports. We obtain information on call protection and maturity dates from the issue prospectuses.

\begin{tabular}{lc}
\hline & Number of observations \\
\hline Called & 159 \\
Merger and acquisition & 105 \\
Bankruptcy & 32 \\
Exchange & 13 \\
Full repurchase & 13 \\
Full exercise of bondholders' right to put & 8 \\
Full voluntary conversion & 4 \\
Matured & 45 \\
Outstanding and call-protected at 1-1-2012 & 45 \\
Outstanding and callable at 1-1-2012 & 47 \\
\cline { 2 - 2 }
\end{tabular}




\section{Table III \\ Call Delay}

Panel A reports call delay for convertibles that are called in-the-money. Panel B reports call delay for non called convertible bonds that are both in-the-money and not callprotected at some time prior to 1-1-2012. Panel C reports call delay for two subsamples of non dividend-protected convertibles that are called in-the-money: high-dividend convertibles with dividends in excess of after-tax coupons, and low-dividend convertibles with dividends less than after-tax coupons. Dividend protection indicates that the conversion rate for the convertible bond is adjusted for regular cash dividends. Cumulative call delay is the number of trading days that the convertible is in-the-money, callable and uncalled. Continuous call delay is the number of trading days that the convertible is continuously in-the-money, callable, and uncalled. The difference in means $t$-statistics do not assume equal variances. ${ }^{* * *},{ }^{* *}$, and $*$ indicate statistical significance at the $1 \%, 5 \%$, and $10 \%$ level, respectively.

\begin{tabular}{|c|c|c|c|c|}
\hline \multicolumn{5}{|c|}{ Panel A: Convertibles classified as called in-the-money } \\
\hline & Mean & Median & St. dev. & Maximum \\
\hline \multicolumn{5}{|c|}{ Non dividend-protected (63 observations) } \\
\hline Cumulative call delay & 67.22 & 0 & 186.30 & 1221 \\
\hline Continuous call delay & 47.30 & 0 & 114.57 & 515 \\
\hline \multicolumn{5}{|c|}{ Dividend-protected (45 observations) } \\
\hline Cumulative call delay & 2.47 & 0 & 6.28 & 24 \\
\hline Continuous call delay & 2.47 & 0 & 6.28 & 24 \\
\hline \multicolumn{5}{|c|}{ Difference in means $t$-statistic } \\
\hline Cumulative call delay & 2.757 & & & \\
\hline Continuous call delay & 3.100 & & & \\
\hline \multicolumn{5}{|l|}{ Bootstrapped z-statistic } \\
\hline Cumulative call delay & 5.455 & & & \\
\hline Continuous call delay & 6.594 & & & \\
\hline
\end{tabular}


Panel B: Convertibles that are not called but are both in-the-money and not callprotected at some time prior to 1-1-2012

\begin{tabular}{|c|c|c|c|c|}
\hline \multicolumn{5}{|c|}{ Non dividend-protected (8 observations) } \\
\hline Cumulative call delay & 232.13 & 168 & 260.08 & 747 \\
\hline Continuous call delay & 209.38 & 143 & 252.70 & 747 \\
\hline \multicolumn{5}{|c|}{ Dividend-protected (3 observations) } \\
\hline Cumulative call delay & 13.00 & 6 & 16.64 & 32 \\
\hline Continuous call delay & 11.33 & 1 & 17.90 & 32 \\
\hline \multicolumn{5}{|c|}{ Difference in means $t$-statistic } \\
\hline Cumulative call delay & $2.370 * *$ & & & \\
\hline Continuous call delay & $2.202 *$ & & & \\
\hline \multicolumn{5}{|l|}{ Bootstrapped z-statistic } \\
\hline Cumulative call delay & $2.639 * * *$ & & & \\
\hline Continuous call delay & $2.846^{* * *}$ & & & \\
\hline \multicolumn{5}{|c|}{$\begin{array}{c}\text { Panel C: Call delay for non dividend-protected convertibles segregated by dividends } \\
\text { relative to after-tax coupons }\end{array}$} \\
\hline & Mean & Median & St. dev. & Maximum \\
\hline \multicolumn{5}{|c|}{ High dividends (19 observations) } \\
\hline Cumulative call delay & 181.37 & 23 & 308.03 & 1221 \\
\hline Continuous call delay & 126.89 & 23 & 182.60 & 515 \\
\hline \multicolumn{5}{|c|}{ Low dividends (44 observations) } \\
\hline Cumulative call delay & 17.93 & 0 & 45.65 & 232 \\
\hline Continuous call delay & 12.93 & 0 & 30.99 & 153 \\
\hline \multicolumn{5}{|c|}{ Difference in means $t$-statistic } \\
\hline Cumulative call delay & $2.302 * *$ & & & \\
\hline Continuous call delay & $2.704 * *$ & & & \\
\hline \multicolumn{5}{|l|}{ Bootstrapped z-statistic } \\
\hline Cumulative call delay & $3.609 * * *$ & & & \\
\hline Continuous call delay & $3.651 * * *$ & & & \\
\hline
\end{tabular}




\section{Table IV \\ Tobit Analysis of Call Delay}

The sample consists of the 108 convertibles issued over the period 2000 to 2008 and called in-the-money before January 1, 2012. The table reports the results of a Tobit analysis of call delay. The dependent variable is the logarithm of $(1+$ call delay). Dividend protection is a dummy equal to one when the conversion rate for the convertible bond is adjusted for regular cash dividends, and zero otherwise. The dividend relative to after-tax coupon variable is the largest annual dividend paid during the bond's life while it is callable multiplied by the conversion ratio and divided by the after-tax coupon. Safety premium is the conversion value on the date conversion could first be forced divided by the call price, minus one. The monthly stock return volatility is for the year before conversion could first be forced. Financial slack is measured as cash plus shortterm investments divided by the call price for the entire issue. The year of call dummies relate to the year in which conversion could first be forced. The dividend to after-tax coupon ratio is winsorized at a value of five and the safety premium at a value of one. Models (3) and (4) focus on the subset of convertibles without dividend protection. We report heteroskedasticity-consistent standard errors in parentheses. ${ }^{* * *},{ }^{* *}$, and $*$ indicate statistical significance at the $1 \%, 5 \%$, and $10 \%$ level, respectively.

\begin{tabular}{|c|c|c|c|c|}
\hline & \multicolumn{4}{|c|}{ Ln(1 + call delay $)$} \\
\hline & \multicolumn{2}{|c|}{$\begin{array}{l}\text { Dividend-protected and non } \\
\text { lividend-protected convertibles }\end{array}$} & \multicolumn{2}{|c|}{$\begin{array}{c}\text { Non dividend-protected } \\
\text { convertibles }\end{array}$} \\
\hline & $\begin{array}{l}\text { Cumulative } \\
\text { call delay } \\
\text { (1) }\end{array}$ & $\begin{array}{l}\text { Continuous } \\
\text { call delay } \\
\text { (2) }\end{array}$ & $\begin{array}{l}\text { Cumulative } \\
\text { call delay } \\
\text { (3) }\end{array}$ & $\begin{array}{l}\text { Continuous } \\
\text { call delay } \\
\text { (4) }\end{array}$ \\
\hline Dividend protection & $\begin{array}{l}-3.442 * * * \\
(1.310)\end{array}$ & $\begin{array}{c}-3.176^{* *} \\
(1.246)\end{array}$ & & \\
\hline Dividend / after-tax coupon & $\begin{array}{c}0.522^{*} \\
(0.279)\end{array}$ & $\begin{array}{c}0.499^{*} \\
(0.271)\end{array}$ & $\begin{array}{l}0.734^{* *} \\
(0.301)\end{array}$ & $\begin{array}{l}0.701^{* *} \\
(0.300)\end{array}$ \\
\hline Safety premium & $\begin{array}{l}-2.213^{*} \\
(1.296)\end{array}$ & $\begin{array}{c}-2.058 \\
(1.252)\end{array}$ & $\begin{array}{l}-3.586 * * \\
(1.470)\end{array}$ & $\begin{array}{l}-3.314^{* *} \\
(1.423)\end{array}$ \\
\hline Stock return volatility & $\begin{array}{c}12.749 \\
(12.860)\end{array}$ & $\begin{array}{r}13.249 \\
(12.348)\end{array}$ & $\begin{array}{c}0.403 \\
(19.496)\end{array}$ & $\begin{array}{c}1.641 \\
(18.892)\end{array}$ \\
\hline $\begin{array}{l}\text { Cash \& short-term } \\
\text { investments / payment } \\
\text { upon calling }\end{array}$ & $\begin{array}{c}-0.137 \\
(0.184)\end{array}$ & $\begin{array}{c}-0.123 \\
0.173)\end{array}$ & $\begin{array}{c}-0.385 \\
(0.300)\end{array}$ & $\begin{array}{c}-0.352 \\
(0.279)\end{array}$ \\
\hline Year of issue dummies & Yes & Yes & Yes & Yes \\
\hline Year of call dummies & Yes & Yes & Yes & Yes \\
\hline Pseudo $R^{2}$ & $8.92 \%$ & $8.71 \%$ & $14.53 \%$ & $14.04 \%$ \\
\hline$N$ & 108 & 108 & 63 & 63 \\
\hline
\end{tabular}




\section{Table V}

\section{Dividend Protection, Hedge Fund Involvement, and JGTRRA 2003}

This table reports results of a logit analysis of the relation between dividend protection, hedge fund involvement, and the passage of JGTRRA. Dividend protection indicates that the conversion rate for the convertible bond will be adjusted for regular cash dividends. The Post-May 2003 dummy takes a value of one for all bonds issued on or after the passage of JGTRRA in May 2003. Following Brown et al. (2012), we capture hedge fund involvement using the fraction of a convertible issue purchased by hedge funds and the fraction of the purchasers involved in a convertible issue that can be classified as hedge funds. Dividend yield is measured as dividends over a fiscal year relative to the fiscal year-end value of equity. Total assets, dividends, and the market value of equity are measured before the offering. Heteroskedasticity-consistent standard errors are reported in parentheses. ${ }^{* * *}$ and ${ }^{* *}$ indicate significance at the $1 \%$ and $5 \%$ level, respectively.

\begin{tabular}{lcc}
\hline & \multicolumn{2}{c}{ Dividend protection } \\
\hline Constant & $-3.077^{* *}$ & $-2.355^{* *}$ \\
& $(1.287)$ & $(1.023)$ \\
Post-May 2003 dummy & $4.448^{* * *}$ & $4.475^{* * *}$ \\
& $(0.418)$ & $(0.424)$ \\
Fraction of proceeds purchased & 1.142 & \\
$\quad$ by hedge funds & $(1.044)$ & \\
$\quad$ Fraction of purchasers that are & & 0.241 \\
$\quad$ hedge funds & & $(0.860)$ \\
Log(assets) & -0.164 & -0.181 \\
& $(0.302)$ & $(0.296)$ \\
Dividend yield & -0.294 & -0.287 \\
& $(0.196)$ & $(0.194)$ \\
& & \\
Pseudo $\mathrm{R}^{2}$ & $48.81 \%$ & $48.59 \%$ \\
$\mathrm{~N}$ & 401 & 401 \\
\hline
\end{tabular}


${ }^{1}$ A call will fail to force conversion if the conversion value drops below the call price at the end of the notice period and convertible bondholders tender their bonds for cash. For models and empirical investigations of the safety premium rationale for call delay, see Ingersoll (1977b), Jaffee and Shleifer (1990), Asquith and Mullins (1991), Asquith (1995), Ederington, Caton, and Campbell (1997), Butler (2002), Altintig and Butler (2005), and King and Mauer (2014).

${ }^{2}$ For empirical investigations of this signaling rationale for call delay, see Ofer and Natarajan (1987), Acharya (1988), Campbell, Ederington and Vankudre (1991), Ederington, Caton, and Campbell (1997), Ederington and Goh (2001), and King and Mauer (2014).

${ }^{3}$ Dunn and Eades (1989) document the existence of many sleeping convertible preferred stockholders.

${ }^{4}$ Constantinides and Grundy (1986) show that call delay is related to future dividends and that call delay by low-dividend firms is a predictor of future dividend growth and voluntary conversion. Campbell, Ederington, and Vankudre (1991) show that firms that do not delay tend to subsequently experience dividend decreases.

${ }^{5}$ Asquith and Mullins (1991) show that calls are less likely when dividends exceed after-tax coupons. Consistent with this observation, Campbell, Ederington, and Vankudre (1991), Asquith (1995), and King and Mauer (2014) report longer average call delays for bonds when dividends exceed after-tax coupons.

${ }^{6}$ An adjustment of the form given in Equation (1) was suggested in Kahan's (1995) analysis of potential anti dilution provisions that might be included in convertible securities. When the stock price drop on the ex-dividend date is smaller than one-for-one (see, for example, Campbell and Beranek (1955), Elton and Gruber (1970), Bali and Hite (1998)), the holders of convertible bonds with dividend protection are actually (slightly) better off when a dividend is paid, in that the conversion value of the bond increases. This observation increases the incentive to call and force 
conversion and does not alter our prediction of low call delay for dividend-protected convertible bonds.

${ }^{7}$ Dividend protection does not mean that dividend-protected convertibles can be valued as if there were no dividends. Although the conversion value of the bond is unaffected by dividend payments, the value of the bond itself is affected. The situation is analogous to that of dividendprotected options (see Geske, Roll, and Shastri (1983), Merton (1973)).

${ }^{8}$ Let $V_{\text {call }}$ denote firm value when a call is announced, $\tau$ the corporate tax rate, and $c$ the coupon payment. The Appendix shows that the original shareholders' claim on the firm is worth $\frac{n}{n+C R_{0}} V_{\text {call }}$ if the firm calls. If the firm delays calling a dividend-protected convertible bond, the original shareholders' claim on the firm is worth at most the lesser amount $\frac{n}{n+C R_{0}}\left(V_{\text {call }}-(1-\tau) P V(c)\right)$.

${ }^{9}$ In the Internet Appendix we show this formally by setting out the parameter restrictions such that a dividend-related signaling equilibrium exists when a convertible is not dividend-protected. We then show that no such equilibrium exists if the convertible is dividend-protected. The Internet Appendix is available in the online version of this article on the Journal of Finance website.

${ }^{10}$ In a scenario in which high dividends induce voluntary conversion, a HR signaling rationale for a delay in calling a non dividend-protected convertible is ruled out. Instead, firms in such a scenario are likely to delay calling a non dividend-protected convertible for a different reason: the high dividend itself brings into play the set of dividend-related rationales for delay. Now consider high dividends and a dividend-protected convertible. Since a dividend-protected convertible will never be voluntarily converted, a HR signaling equilibrium might explain a delay for a dividend-protected convertible yet be ruled out for a non dividend-protected convertible. 
Hence, when dividends are high, dividend protection might change the rationale for the delay but not its existence (see Internet Appendix Section II.C).

${ }^{11}$ We present these results in Internet Appendix Section II. Section II.A of the Internet Appendix determines the parameter space consistent with the existence of a HR signaling equilibrium when the convertible is not dividend-protected. Section II.B of the Internet Appendix determines the parameter space consistent with the existence of a HR signaling equilibrium when the convertible is dividend-protected. Section II.C of the Internet Appendix compares the likelihood of call delay for non dividend-protected and dividend-protected convertibles and concludes that call delay for non dividend-protected convertibles is comparable to that of dividend-protected convertibles.

${ }^{12}$ We also collected convertibles issued from January 2009 until December 2011 with call features and an offering prospectus available on the SEC's Edgar database. All of these issues are still in their call protection period as of 1-1-2012, and thus are not informative about call delay. Note that all these convertibles are dividend-protected.

${ }^{13}$ To estimate the marginal corporate tax rate, we use Graham's simulated tax database (available at http://faculty.fuqua.duke.edu/ jgraham/taxform.html) and multiply the annual coupon payment by one minus the firm's marginal corporate tax rate in the year of the offering. A robustness test that uses a 35\% corporate rate throughout does not change our conclusions.

${ }^{14}$ None of our conclusions are changed if we exclude all convertibles with minimum threshold amounts and yields from our analysis.

${ }^{15}$ We obtain information on conversion rates and call schedules from the issue prospectuses. We adjust the conversion rate for stock dividends, stock splits, and extraordinary cash dividends. For dividend-protected convertible bonds we also adjust the conversion rate for regular cash dividends. When there is a minimum threshold amount or yield specified for regular cash dividends, we adjust the conversion rate only for those dividends that exceed the minimum threshold. 
${ }^{16}$ Ingersoll (1977b) shows that absent underwriting costs, the optimal call policy in the presence of a call notice period is to call when the bond is just out-of-the-money. Seven of the eight bonds that were called just out-of-the-money were not dividend-protected, and including these eight bonds reduces the average delay for non dividend-protected bonds relative to dividend-protected bonds. Therefore, excluding the eight bonds only strengthens the paper's finding of a lower call delay for dividend-protected bonds relative to non dividend-protected bonds.

${ }^{17}$ When combining the observations in Panels A and B, we have the full set of convertibles in our sample that were both in-the-money and not call-protected at any time prior to 1-1-2012. The mean (median) cumulative call delay for all non dividend-protected convertibles is 85.80 (65.56) days. For all dividend-protected convertibles, the mean (median) cumulative delay is 3.13 (3.02) days. The shorter cumulative delay for dividend-protected convertibles relative to non dividendprotected convertibles is significant at the $1 \%$ level. A comparison of the continuous delay measures of the complete set of convertibles in the dividend-protected and non dividendprotected groups leads to the same conclusion.

18 The time between when conversion could have first been forced and the bond's eventual demise will include any days in this interval on which the conversion option was out-of-themoney. It is this measure that is relevant to determining the additional coupons paid because conversion was not forced at the earliest opportunity.

${ }^{19}$ Campbell, Ederington, and Vankudre (1991) examine calls between 1962 and 1985 and report an average delay of 3.32 years, whereas Asquith (1995) reports a shorter average delay over the 1980 to 1993 period of 170.5 days. King and Mauer (2014) examine convertibles issued between 1980 and 2002 and find that for the bonds issued between 1980 and 1989 the average delay is 147 days, whereas for the bonds issued between 1990 and 2002 the average delay is only 41 days.

${ }^{20}$ In Internet Appendix Section III, we further investigate the safety premium and confirm that a desire for a safety premium may help explain the delay by non dividend-paying firms with non 
dividend-protected convertibles. Internet Appendix Section IV shows that the decline in call delay for non dividend-protected convertibles has occurred over a period during which both the likelihood and the size of dividend payments declined, which is consistent with the importance of dividend-related rationales for delay.

${ }^{21}$ An article in a practitioner journal, Ferreira and Ouzou (2011), attributes the design change to the passage of the JGTRRA and a belief that dividends would increase. 